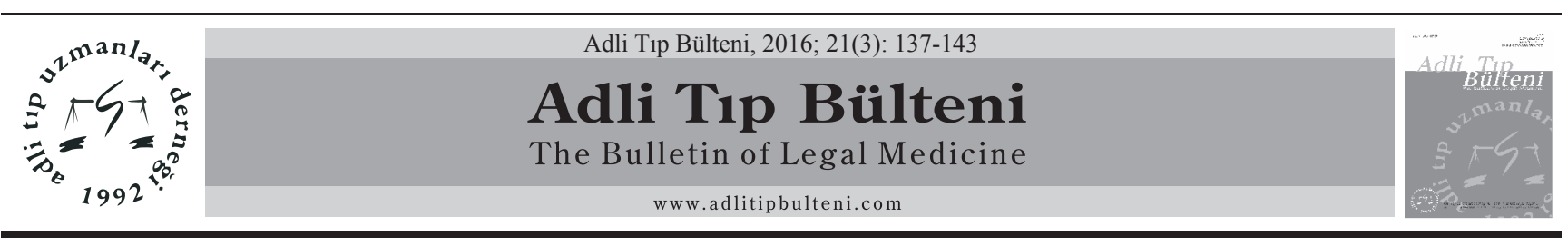

ARAŞTIRMA / RESEARCH ARTICLE

doi: 10.17986/blm.2016323746

\title{
Cinsel İstismara Uğrayan Çocuk ve Ergenlerin Kendine Zarar Verme, İntihar Davranışı ve Psikiyatrik Bozukluklar Açısından Değerlendirilmesi
}

\author{
Assesment of Sociodemoghraphic Data, Self Mutilation, Suicide Attempt and \\ Psychiatric Disorders in Children and Adolescents who Abused Sexually \\ Merve Çıkılı Uytun ${ }^{1}$, Rabia Yılmaz², Didem Behice Öztop ${ }^{3}$, Çăglar Özdemir ${ }^{4}$ \\ ${ }^{1}$ Kayseri Eğitim Araştırma Hastanesi, Çocuk Psikiyatrisi Bölümü, Kayseri \\ ${ }^{2}$ Kilis Devlet Hastanesi, Çocuk Psikiyatrisi Bölümü, Kilis \\ ${ }^{3}$ Çocuk Psikiyatrisi, Boylam Psikiyatri Enstitüsü, Ístanbul \\ ${ }^{4}$ Erciyes Üniversitesi Tıp Fakültesi Adli Tip Anabilim Dall, Kayseri
}

\section{Özet}

Amaç: Çocukluk çağı cinsel istismarının ilerleyen yıllarda kendine zarar verme, intihar, depresyon, disosiyatif bozukluk, travma sonrası stres bozukluğu (TSSB)gibi bozukluklarla ilişkili olduğu bilinmektedir. Bu çalışmada istismara uğrayan çocuk ve ergenlerin özelliklerinin, kendine zarar verme ve intihar davranıșı oranları ile depresyon, TSSB ve disosiyatif bozukluk oranlarının belirlenmesi ve aralarındaki ilişkinin incelenmesi amaçlanmıştır.

Gereç ve Yöntem: Erciyes Üniversitesi Tıp Fakültesi Çocuk Psikiyatri Polikliniğine 01.01.2011-31.12.2011 tarihleri arasında adli rapor düzenlenmesi amacıyla gönderilen cinsel istismara maruz kalmış 0-18 yaş arası olgular; yaş, cinsiyet, istismar sıklığı, DSM IV-TR tanı sınıflamasına göre psikiyatrik tanıları, evden kaçma hikayesi ile intihar davranışı açısından retrospektif olarak incelendi. Aileler ve çocuklar tarafindan doldurulan Çocuklar için depresyon ölçeği(ÇDÖ), disosiasyon ölçeği(DIS-Q) ve Çocuklar için travma sonrası stres tepki ölçekleri (ÇTSS-TÖ)retrospektif olarak incelendi.

Bulgular: Çalışmamızda toplam 556 olgu değerlendirilmiştir. Başvuruları sırasında 24'nün $(\% 4,3)$ intihar girişiminde bulunduğu, 15 'inin(\%2,7) kendine zarar verme davranışında bulunduğu, 6's1nın $(\% 1,1)$ intihar fikrine sahip olduğu belirlendi. Travma sonrası stres tepki ölçeği verilen vakaların 33'ünde $(\% 5,6)$ ÇTSS-TÖ ölçeği puanı TSSB için anlamlı kabul edilen 40 değerinin üstünde bulundu. DIS-Q ölçeği verilen vakaların 8 'inde $(\% 1,6)$ DIS-Q ölçeği anlamlı olarak kabul edilen 2,5 değerinin üstünde bulundu. ÇDÖ ölçeği verilen vakaların 42 'sinde $(\% 7,3)$ depresyon ölçeği değerleri depresyon için anlamlı olarak kabul edilen 19 değerinin üzerinde bulundu.

Sonuç: Cinsel istismara uğramış çocukları yakından takip etmek, onların sadece ruh sağlı̆̆ını korumak için değil, aynı zamanda yine bir kurban olmaktan onları uzak tutmak ve intihar ile kendini yaralama davranışlarını önlemek için de çok önemlidir.

Anahtar Kelimeler: Çocuk; Ergen; Cinsel İstismar.

\section{Abstract}

Objective: It is now generally known that undergoing a sexual abuse may lead to self-destruction, suicide, post-traumatic stress disorder (PTSD), depression and dissociative disorders. Our study aims at determining the rate of self-destruction and suicide among children who had experienced sexual abuse and determining the rates of depression, PTSD and dissociative disorders and their relationships each other.

Materials and Methods: The children aged 0-18 who had undergone sexual abuse and sent to Prevention of Child Abuse, Application and Research Center at Erciyes University between 01.01.201131.12.2011 to have a judicial report were analyzed retrospectively with regard to their age, sex, frequency of abuse, psychiatric diagnosis according to DSM IV-TR and leaving home or suicide behaviours. The children were made to complete Depression Scale for Children (CDI), Child Post-Traumatic Stress Reaction Index (RPTS-CS) and Dissociation Ouestionnaire (DIS-Q).

Results: 556 cases was included in our research. There was suicide attempt in $24(4,3 \%)$ of them, $15(2,7 \%)$ had the behaviour of self-mutilation, $6(1,1 \%)$ of them had the idea to commit suicide. In the scales, RPTS-CS was found significantfor $33(5,6 \%)$ cases. The score of the DIS-Q was found significant for $8(1,6 \%)$ cases $(>2,5)$. The mean score of the CDI was found significant for $42(7,3 \%)$ cases $(>19)$.

Conclusion: It is not only important to follow up closely the children who had experienced sexual abuse and to protect their mental health, but also it is very important to keep them away from being a victim again and prevent to commit suicide and self mutilation behaviors.

Keywords: Child; Adolescent; Sexual Abuse.
Sorumlu Yazar: Merve Çıkılı Uytun

Kayseri Eğitim Araştırma Hastanesi, Emel-Mehmet Tarman Çocuk Hastanesi Çocuk ve Ergen Ruh Sağlığı ve Hastalıkları, Kayseri

E-posta: mervecikili@yahoo.com

*Bu çalışmanın bir kısmı 19. International Congress on Child Abuse and Neglect, 9-12 Eylül 2012' de poster bildiri olarak sunulmuştur.

Geliş:09.05.2016 Düzeltme:30.06.2016 Kabul:11.07.2016

\section{Giriş}

Çocuğun cinsel istismarı kavramı Türk Ceza Kanununda (TCK) “on beş yaşını tamamlamamış veya tamamlamış olmakla birlikte fiilin hukuki anlam ve sonuçlarını algılama yeteneği gelişmemiş olan çocuklara karşı gerçekleştirilen her türlü cinsel davranış, diğer çocuklara karşı sadece cebir, tehdit, hile veya iradeyi etkileyen baş- 
ka bir nedene dayalı olarak gerçekleştirilen cinsel davranışlar" olarak tanımlanmaktadır (1).

Cinsel istismarın toplumda sıklığına bakıldığında, metodolojik farklardan dolayı çalıșmalarda bildirilen cinsel istismar yaygınlık oranları arasında büyük farklar bulunmaktadır (2). Genel epidemiyolojik veriler oluşturulması amaciyla 2011 yılında yapılan bir meta analizde, 1982 ve 2008 yılları arasında cinsel istismar sıklığ ile ilgili 217 makale taranarak toplam 331 bağımsız örnekten 9.911.748 katılımcıdan veriler elde edilmiştir.Bu meta analize göre Dünya'da prevalans \%11.8 veya her 1000 çocukta 118 olarak saptanmıştır. Cinsiyetlere bakıldığında ise kadınlarda \%18, erkeklerde \%7.6 olarak bulunmuştur (3). Çocukların değerlendirildiği cinsel istismar çalışmalarını kapsayan bir metaanaliz çalışmasında ise kızlarda cinsel istismar sıklığının \% 8-31, erkeklerde ise \% 3-17 oranında olduğu bildirilmiştir (4). Literatürde tutarlı olarak cinsel istismara maruz kalma sıklığının kızlarda, erkeklere oranla 1.5 -5.5 kat daha fazla görüldüğü bildirilmektedir (4-6).

Çocuklarda cinsel istismar sıklığının zaman içindeki değişimi konusu tartışmalı olmakla birlikte bazı araştırmacılar 1990'ların ortasından 2005 yılına kadar olan süreçte çocuklarda cinsel istismar sıklığında azalma saptarken (7), diğer araştırmacılar zaman içinde böyle bir değişim bulmamışlardır (8).

İstismarın neden olduğu utanç, suçluluk gibi tepkilerden dolayı cinsel istismar çoğu kez gizli olarak kalmakta ve sır olarak saklandığ 1 için de gerçek istatistiksel verilere ulaşmak zor olmaktadır (9). Stoltenborgh ve arkadaşlarının metaanaliz çalışmasında öz bildirim ölçeklerine dayalı çalışmalarda (1000 de 127), resmi raporlara dayalı verilere (1000 de 4) göre 30 kat daha fazla oranda cinsel istismar oranları elde edildiği saptanmıştır. Başka bir deyişle, 8 kişiden 1'i cinsel istismara maruz kaldığını söylerken, bu 250 çocuktan sadece 1'inin resmi olarak bildirildiğini göstermektedir (3). Bu oranlar cinsel istismar vakalarının çoğunun buzdağının altında kaldığının trajik bir göstergesidir.

Cinsel istismarın çocuğun ruhsal yaşantısına etkisi ise son derece karmaşıktır ve çocukların bireysel farklılıklarına ve gelişim dönemlerine, istismarın tipi, süresi ve şiddetine, çocuk ile istismarcı arasındaki ilişkiye göre değişiklikler gösterebilir (9). Literatürde cinsel istismara uğrayan çocuk ve ergenlerin çocukluk çağından erişkinliğe dek uzanan çeşitli psikiyatrik bozukluklar geliştirdiği bildirilmiştir. Çocuklarda cinsel istismarın sonucunda kaygı bozuklukları, disosiatif yaşantılar, kendine zarar verme ve intihar davranışları, uyku bozuklukları, duygudurum bozuklukları, travma sonrası stres bozuklukluğu (TSSB), davranım ve cinsel davranış bozuklukları, alkol ve madde kötüye kullanımı ve yeme bozuklukları görülebilir $(10,11)$. Uzun dönem etkilerine bakıldığında ise çocukluk çağında cinsel istismara maruz kalma öyküsünün yetişkinlik döneminde; depresyon, anksiyete bozuklukları, yeme bozuklukları, madde kötüye kullanımı, intihar davranışı, kişilik bozuklukları, uyku bozuklukları, travma sonrası stres bozukluğu ve disosiatif bozukluklar ile ilişkili olduğu gösterilmiştir (12-14). Cinsel istismar mağduru çocukların hayatlarında kısa ve uzun vadede tahrip edici sonuçları göz önüne alındığında çocuklarda cinsel istismar konusunun toplumsal ve bilimsel alanlarda ilgi çeken bir konu haline gelmesi kaçınılmaz olmaktadır (5).

Bu çalışmada; Erciyes Üniversitesi tıp fakültesi çocuk psikiyatrisi polikliniklerine adli değerlendirme istemiyle gönderilen çocukların sosyodemografik özelliklerinin, psikiyatrik tanılarının, kendine zarar verme ve intihar davranışlarının, dissosiasyon, depresyon ve travma sonrası stres bozukluğu belirtilerinin DSM-IV tanı kriterlerine göre yapılan psikiyatrik değerlendirme ve ölçeklerle araştırılması ve bunların birbiriyle ilişkilerinin incelenmesi amaçlanmıştır.

\section{Gereç ve Yöntem}

Erciyes Üniversitesi Tıp Fakültesi Çocuk Psikiyatri Polikliniğine 01.01.2011-31.12.2011 tarihleri arasında adli rapor düzenlenmesi amacıyla gönderilen cinsel istismara maruz kalmış $0-18$ yaş arası 664olgu ilgili adli raporlar ve ölçekler; yaş, cinsiyet, istismar sıklığı, DSM IV-TR tanı sınıflamasına göre psikiyatrik tanıları, evden kaçma hikayesi ile intihar davranışı açısından retrospektif olarak incelendi. Ailesi ile gelmemiş olan, iletişim kurulamayan, görüşme yapmayı reddeden ve sosyodemografik veri formunda yeterli veri bulunmayan 108 olgu çalışma dışı bırakıldı ve toplam 556 olgunun verileri değerlendirildi. Olguların tümünün, bütün sosyodemografik verilerine ulaşılamadığı için vaka sayıları, farklı sosyodemografik veriler ve ölçeklerde farklılık göstermektedir. Aileler ve çocuklar tarafindan doldurulan Çocuklar için depresyon ölçeği (ÇDÖ), Dissosiasyon ölçeği (DIS-Q) ve Çocuklar için travma sonrası stres tepki ölçekleri (ÇTSSTÖ) retrospektif olarak incelendi. Erciyes Üniversitesi Etik Kurulundan çalışma ile ilgili izin alınmıştır.

Analizlerde SPSS 17.00 İstatiksel Paket Programı kullanılarak tanımlayıcı istatistikler ve korelasyon analizleri yapıldı. Cinsiyet karşılaştırmalarında bağımsız t-test ve ki-kare testleri kullanıldı. Kullanılan ölçeklerle ilgili detaylı bilgi aşağıda sunulmuştur.

Çocuklar için Depresyon Ölçeği (ÇDÖ): Kovacs (1980) tarafından geliştirilmiş olan bu ölçek 27 maddeden oluşmaktadır. Her madde belirtinin şiddetine göre 0 , 1 ya da 2 olarak puanlanmaktadır (15). Ölçeğin ülkemiz- 
de geçerlik ve güvenilirlik çalışması yapılmış ve kesme puanı 19 olarak belirlenmiştir (16).

Dissosiasyon Ölçeği (DIS-Q); Dissosiasyon ölçeği Vanderlinden ve arkadaşları tarafından geliştirilmiş olan vaka tarafindan doldurulan 63 maddeden oluşan bir ölçektir. Maddeler 1-5 arası puanlanmaktadır. Toplam puan 63 'e bölünerek elde edilen değerin 2,5'un üzerinde olmas1 anlamlı kabul edilmektedir (17). Ölçeğin Türkçe geçerlilik ve güvenilirliği Şar ve arkadaşları (1997) tarafından yapılmıştır (18).

Çocuklar için Travma sonrası Stres Tepki Ölçeği (ÇTSS-TÖ); ÇTSS-TÖ çeşitli travmatik yaşantılar sonrasında çocuk ve ergenlerde ortaya çıkan stres tepkilerini

Tablo 1. İstismara Uğrayanların Sosyodemografik Özellikleri.

\begin{tabular}{|c|c|c|}
\hline $\begin{array}{l}\text { Sosyodemografik } \\
\text { özellikler }\end{array}$ & $\begin{array}{l}\text { Kişi } \\
\text { sayısı (n) }\end{array}$ & Oranlar $(\%) *$ \\
\hline Cinsiyet & 556 & $\begin{array}{l}\text { K1z: \%81,7 } \\
\text { Erkek:\%18,3 }\end{array}$ \\
\hline Yaşadıkları yer & 497 & $\begin{array}{l}\text { Şehir merkezi: } \% 60,1 \\
\text { İlçe: } \% 27,1 \\
\text { Köy: } \% 2,1\end{array}$ \\
\hline Anne yaş & 339 & $\begin{array}{l}20-30 \text { yaş: } \% 4,5 \\
31-40 \text { yaş: } \% 34,6 \\
41-50 \text { yaş: } \% 16,9 \\
51-60 \text { yaş: } \% 5\end{array}$ \\
\hline $\begin{array}{l}\text { Anne eğitim } \\
\text { durumu }\end{array}$ & 284 & $\begin{array}{l}\text { Okur yazar değil: } \% 6,5 \\
\text { Okur yazar: \%4,5 } \\
\text { İlköğretim: \%36,2 } \\
\text { Lise: } \% 4\end{array}$ \\
\hline Baba yaş & 318 & $\begin{array}{l}20-30 \text { yaş: } \% 0,5 \\
31-40 \text { yaş: } \% 19,2 \\
41-50 \text { yaş: } \% 26,6 \\
51-60 \text { yaş: } \% 8,6 \\
61 \text { yaş ve üstü: } \% 2,2\end{array}$ \\
\hline $\begin{array}{l}\text { Baba eğitim } \\
\text { durumu }\end{array}$ & 271 & $\begin{array}{l}\text { Okur yazar değil: } \% 3,4 \\
\text { Okur yazar: } \% 4 \\
\text { İlköğretim: } \% 33,6 \\
\text { Lise: } \% 7,7\end{array}$ \\
\hline Kardeş sayısı & 395 & $\begin{array}{l}\text { Kardeşi yok: } \quad \% 1,4 \\
3 \text { ten az: } \% 18,5 \\
3 \text { ve üzeri: } \% 51,2\end{array}$ \\
\hline Aile durumu & 417 & 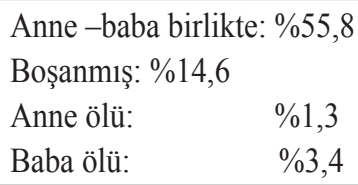 \\
\hline $\begin{array}{l}\text { Ailede alkol } \\
\text { kullanımı }\end{array}$ & 289 & $\begin{array}{l}\text { Var: } \% 13,3 \\
\text { Yok: } \% 38,7\end{array}$ \\
\hline $\begin{array}{l}\text { Ailede psikiyatrik } \\
\text { hastalık öyküsü }\end{array}$ & 261 & $\begin{array}{ll}\text { Var: } & \% 9,9 \\
\text { Yok: } & \% 37,1\end{array}$ \\
\hline
\end{tabular}

değerlendirmek için Pynoos ve arkadaşları (1987) tarafından geliştirilmiştir. 20 maddelik likert tipi yarı yapılandırılmış bir ölçektir. Toplam puanın 12-24arasında olması hafif, 25-39 arası orta düzeyde,40-59 arası ağır ve 60 puanın üstü çok ağır TSSB belirtilerine işaret etmektedir (19). 40 ve üzerindeki puanların klinik TSSB tanısı ile korele olduğu gösterilmiştir (20). Türkçe geçerlik-güvenirlik çalışması Erden ve arkadaşları (1999) tarafından yapılmıştır (21).

\section{Bulgular}

Yapılan değerlendirmeler sonucunda çalışmaya dâhil edilen 556çocuktan 454'ünün(\%81,7) cinsiyetinin k1z, $102 \operatorname{sinin}(\% 18,3)$ ise erkek olduğu ve çocukların yaş ortalamasının 13,65 $\pm 3,24$ olduğu belirlendi. Vakaların dosyalarında tüm bilgilere ulaşılamaması, verilen sosyodemografik veri formlarını eksik veya geçersiz doldurmaları nedeniyle, her bir sosyodemografik özellik ile ilgili farklı sayıda vakaya ulaşılabilmiştir. Bulgularda verilen yüzdeler çalışmadaki tüm hasta sayısına göre verilmiştir.

Vakaların sosyodemografik verileri Tablo 1'de gösterilmiştir.

Olgu üzerinden hesaplanarak verilmiştir.İstismarın sayısı, cinsel istismarın türü, istismarı yapan kişi, istismarcıların yaşları gibi istismar ile ilişkili özellikler Tablo 2'de özetlenmiştir.

*Tablodaki yüzdeler toplam olgu sayısı olan 556 olgu üzerinden hesaplanarak verilmiştir.

Olguların ruhsal değerlendirme sonucunda DSM-IV tanı sınıflamasına göre yapılan psikiyatrik değerlendirme sonuçlarına bakıldığında, sonuçlarına ulaşılabilen294 $(\% 52,9)$ vakanın; 131 'inde (\% 23,6) psikopatoloji saptanmazken, $77(\%$ 13,8) vakada travma sonrası stres bozukluğu (TSSB), $51(\% 9,2)$ vakada uyum bozukluğu (UB), $35(\% 6,3)$ vakada depresyon tanıları saptanmıştır. Olguların 262'sinin (\%47,1) sonuçlarına ulaşılamamıştır.

Olguların başvuruları sırasında herhangi bir riskli davranışta ve/veya intihar girşiminde bulunup bulunmadı̆̆ sorusunun cevabına $119(\% 21,4)$ vakada ulaşılabilmiş, bu vakaların 74'ünün $(\% 13,3)$ herhangi bir riskli davranışta bulunmadığı, 24'ünün(\%4,3) intihar girişiminde bulunduğu, 15'inin(\%2,7) kendine zarar verme davranışında bulunduğu, 6'sının(\%1,1) intihar fikrine sahip olduğu belirlendi. Olguların 437'sinde $(\% 78,6)$ bu sorunun cevabına ulaşılamadı. Evden kaçıp kaçmadığı sorusuna cevap alınabilen 288vakanın(\%51,8) 125'inin(\%22,5) evden kaçma hikâyesinin olduğu belirlendi. 268 (\%48,2) olguda bu konu ile ilgili bilgiye ulaşılamadi.

Travma sonrası stres tepki ölçeği 86vakaya verilmiştir. ÇTSS-TÖ ortalama değeri $36,7 \pm 17,8$ olarak bulunmuştur. Vakaların 33'ünde $(\% 5,6)$ ÇTSS-TÖ ölçeği puanı 
TSSB için anlamlı kabul edilen 40 değerinin üstünde bulunmuştur.

DIS-Q ölçeği 23 vakaya verilmiştir ve ortalama değer $4,04 \pm 8,5$ olarak bulunmuştur. Vakaların 8 'inde $(\% 1,6)$ DIS-Q ölçeği anlamlı olarak kabul edilen 2,5 değerinin üstünde bulunmuştur.

ÇDÖ ölçeği 92vakaya verilmiştir ve ortalama değer

Tablo 2. İstismar ile İlişkili Özellikler.

\begin{tabular}{|c|c|c|}
\hline $\begin{array}{l}\text { İstismar } \\
\text { ile İlişkili } \\
\text { Özellikler }\end{array}$ & $\begin{array}{l}\text { Kişi } \\
\text { sayısı (n) }\end{array}$ & Oranlar (\%)* \\
\hline $\begin{array}{l}\text { İstismar } \\
\text { say1s1 }\end{array}$ & 411 & $\begin{array}{l}5 \text { kez: } \% 24,1 \\
4 \text { kez: } \% 1,3 \\
3 \text { kez:\%5,8 } \\
2 \text { kez: } \% 8,1 \\
1 \text { kez: } \% 34,2\end{array}$ \\
\hline $\begin{array}{l}\text { İstismarı } \\
\text { yapan kişi }\end{array}$ & 492 & $\begin{array}{l}\text { Erkek arkadaş: } \% 35,4 \\
\text { Tanıdık herhangi biri: \%19,4 } \\
\text { Hiç tanımadıkları kişiler: \%9,2 } \\
\text { Eşleri: } \% 6,3 \\
\text { Arkadaş: \%4,7 } \\
\text { Komşu -komşu çocukları: \%3,8 } \\
\text { Üvey baba: \%2,3 } \\
\text { Öz baba: \%1,6 } \\
\text { Öğretmen: } \% 1,3\end{array}$ \\
\hline $\begin{array}{l}\text { İstismarcının } \\
\text { yaşı }\end{array}$ & 337 & $\begin{array}{l}15 \text { yaş altı: } \% 4,1 \\
15-18 \text { yaş: } \% 14,9 \\
19-25 \text { yaş: } \% 24,7 \\
26-35 \text { yaş: } \% 7,6 \\
36-45 \text { yaş: } \% 6,1 \\
46-55 \text { yaş: } \% 2,3 \\
55 \text { yaş ve üzeri: } \% 0,9\end{array}$ \\
\hline $\begin{array}{l}\text { İstismarın } \\
\text { türü }\end{array}$ & 487 & $\begin{array}{l}\text { Vajinal ilişki: \%28,2 } \\
\text { Anal ilişki: \%14,9 } \\
\text { Özel bölgelere dokunma: \%13,8 } \\
\text { Sürtünme: \%12,1 } \\
\text { Vajinal ve anal ilişki: } \% 7,7 \\
\text { Diğer: } \% 4,5 \\
\text { İstismarı inkâr eden:\%5,6 }\end{array}$ \\
\hline Darp & 125 & $\begin{array}{l}\text { Var: } 55(\% 9,9) \\
\text { Yok: } 70(\% 12,6)\end{array}$ \\
\hline $\begin{array}{l}\text { Fizik } \\
\text { muayene } \\
\text { bulgusu } \\
\text { varlığı }\end{array}$ & 361 & $\begin{array}{l}\text { Var: } 195(\% 35,1) \\
\text { Yok: } 178(\% 29,9)\end{array}$ \\
\hline $\begin{array}{l}\text { Fizik } \\
\text { muayene } \\
\text { bulgusunun } \\
\text { yeri }\end{array}$ & 197 & $\begin{array}{l}\text { Vajinal: } \% 21,4 \\
\text { Anal: } \% 8,6 \\
\text { Vajinal ve anal: } \% 5,4\end{array}$ \\
\hline
\end{tabular}

*Tablodaki yüzdeler toplam olgu sayısı olan 556
$18,8 \pm 12,5$ olarak bulunmuştur. Vakaların 42 'sinde $(\% 7,3)$ depresyon ölçeği değerleri depresyon için anlamlı olarak kabul edilen 19 değerinin üzerinde bulunmuştur. İstismar ile ilișkili ruhsal özellikler Tablo 3 ’te özetlenmiştir.

Tablo 3. İstismar ile İlgili Ruhsal Özellikler.

\begin{tabular}{|c|c|c|}
\hline $\begin{array}{l}\text { İstismar } \\
\text { ile ilişkili } \\
\text { Ruhsal } \\
\text { Özellikler }\end{array}$ & $\begin{array}{l}\text { Kişi } \\
\text { sayısı (n) }\end{array}$ & Oranlar (\%)* \\
\hline $\begin{array}{l}\text { Psikiyatrik } \\
\text { tanı }\end{array}$ & 294 & $\begin{array}{l}\text { TSSB**: } \% 13,8 \\
\text { UB***: } \% 9,2 \\
\text { Depresyon: } \% 6,3 \\
\text { Psikopatoloji yok: \%23,6 }\end{array}$ \\
\hline $\begin{array}{l}\text { Cinsel } \\
\text { istismar } \\
\text { sonrası } \\
\text { ruhsal } \\
\text { etkilenme } \\
\text { durumu }\end{array}$ & 327 & $\begin{array}{l}\text { Etkilenmiş: \%34 } \\
\text { Etkilenmemiş: \%24,8 }\end{array}$ \\
\hline $\begin{array}{l}\text { Riskli } \\
\text { davranış }\end{array}$ & 119 & $\begin{array}{l}\text { Riskli davranış yok: \%13,3 } \\
\text { İntihar girişimi: } \% 4,3 \\
\text { Kendine zarar verme } \\
\text { davranışı: } \% 2,7 \\
\text { İntihar düşüncesi: } \% 1,1\end{array}$ \\
\hline $\begin{array}{l}\text { Evden } \\
\text { kaçma }\end{array}$ & 288 & $\begin{array}{l}\text { Var: \%22,5 } \\
\text { Yok: \%29,3 }\end{array}$ \\
\hline $\begin{array}{l}\text { Travma } \\
\text { sonrası stres } \\
\text { tepki ölçeği }\end{array}$ & 87 & $\begin{array}{l}40 \text { puan ve üzeri: } \% 5,6 \\
40 \text { puanın altı: } \% 9,9\end{array}$ \\
\hline $\begin{array}{l}\text { Depresyon } \\
\text { ölçeği }\end{array}$ & 92 & $\begin{array}{l}19 \text { puan ve üzeri: } \% 7,3 \\
19 \text { puanın altı: } \% 9,2\end{array}$ \\
\hline $\begin{array}{l}\text { Dissosiasyon } \\
\text { ölçeği }\end{array}$ & 23 & $\begin{array}{l}2,5 \text { puanın üzeri: } \% 1,6 \\
2,5 \text { puanın altı: } \% 2,5\end{array}$ \\
\hline
\end{tabular}

*Tablodaki yüzdeler toplam olgu sayısı olan 556 olgu üzerinden hesaplanarak verilmiştir. **TSSB: Travma Sonrası Stres Bozukluğu ***UB: Uyum Bozukluğu

Cinsiyetler arası sosyodemografik özellikler ve ruhsal özellikler açısından fark olup olmadığı incelendiğinde kızların yaş ortalamasının $(14 \pm 2,9)$, erkeklere kıyasla $(11,87 \pm 3,6)$ anlamlı derecede yüksek olduğu $(p<0,001)$, evden kaçma öyküsünün kızlarda daha fazla olduğu $(\mathrm{p}<0,001)$ saptand1.

Korelasyon analizleri yapıldığında, istismarın nitelikli cinsel istismar olması ile yaş $(p<0,001)$, istismar sayıs1 $(p<0,001)$ ve evden kaçma $(p<0,001)$ arasında pozitif korelasyon olduğu, evden kaçma hikâyesinin ayrıca yaş $(p<0,001)$ ile pozitif korele olduğu $(p \leq 0,005)$, kızlarda fazla olduğu $(p<0,001)$ ve DIS-Q ölçeği puanları 
$(p<0,005)$ ile korele olduğu saptandı. İntihar girişimi varlığ 1 ile kı cinsiyette olma $(\mathrm{p}<0,05)$, cinsel istismardan etkilenmiş olma $(p<0,001)$ ve depresyon ölçeği puanları $(p<0,005)$ arasında pozitif korelasyon olduğu bulundu. İstismarcının yaşı ve istismar sayısı $(\mathrm{p} \leq 0,001)$ arasında da pozitif bir korelasyon saptandı. Ruhsal açıdan etkilenme ile istismarcının yaşı arasında da zayıf bir pozitif korelasyon $(\mathrm{p}<0,05)$ saptand 1 .

\section{Tartışma ve Sonuç}

Ülkemizde cinsel istismar ile ilişkili sosyodemografik verilerin ve klinik özelliklerinin değerlendirildiği çeşitli çalışmalar mevcuttur.

Ülkemizde yapılan iki çalışmada çocuk psikiyatrisine yönlendirilen istismar olgularında ortalama yaş 11.4 ve 12.6 yll olarak bildirilmiştir $(22,23)$. Bizim çalışmamızda ise 13.6 olarak daha yüksek yaş ortalaması bulunmuştur. Çalışmalarda kız erkek oranları $7 / 3$ ve $8 / 2$ iken $(22,23)$ bizim çalışmamızda da bu çalışmalara benzer şekilde $8 / 2$ olarak bulunmuştur. Cinsel istismara maruz kalma ile ilgili savunmasızlık, 7-13 yaşlar arasında pik yapmaktadır (24). Cinsel istismar kurbanlarının \%53'ünün 14 yașın altında olduğu yapılan bir çalışmada gösterilmiştir (25). Ancak bu çalışmada literatürden farklı olarak istismara uğrayanların sadece $\% 32,4$ 'ünün 14 yaş altında olduğu, geri kalan olguların 14 yaş üstünde olduğu bulundu. Kızların yaş ortalamalarının genel olarak erkeklerden daha yüksek olduğu bildirilmektedir $(22,26)$. Literatür bilgisiyle uyumlu şekilde bu çalışmada da kızların yaş ortalamaları erkeklerden daha yüksektir. Çalışmamızda kız oranının yüksek olmasının genel yaş ortalamasını artırmış olabileceği düşünülmektedir.

Ülkemizde istismarcıların özelliklerinin değerlendirildiği çok merkezli bir çalı̧̧mada istismarcıların \%78'inin mağdurun ailesinden veya tanıdık biri olduğu bulunmuştur (27). Bu çalışma da ise istismarı yapan kişinin aileden veya mağdurun daha önce tanıdığı, ilişkide bulunduğu birisi olma oranı $\% 90,8$ 'dir. Bu oran çalışmamızda birçok çalışmaya göre oldukça yüksek oranda bulunmuştur. Bunun nedeni olarak insanların yabancı kişilere güvenlerinin azalmış olması ve onlara karşı daha temkinli davranmaları sonucunda tanıdık olmayan kişiler tarafından yapılan istismarların azalması, göreceli olarak da tanıdık kişiler tarafindan yapılan istismar eylemlerinin artması olarak düşünülmektedir.

Çocuklarda cinsel istismar sonrası normal olarak sonuçlanan muayene oranları 6\%-99\% arasında geniş bir aralıkta değişmektedir (28). Bizim çalışmamızda ise 361vaka fizik muayene bulgusu açısından araştırılmış, 195 'inde fizik muayene bulgusu varlığı saptanmıştır. Çalışmamızda fizik muayene bulgusunun varlığıyla, evden kaçma arasındaki ilişki, nitelikli cinsel istismarın ruhsal açıdan daha zedeleyici olması ve nitelikli cinsel istismar sonrası aile ve çevre baskısının çocuk üzerinde olumsuz etkileri ile ilişkili olabileceği şeklinde yorumlanmıştır.

Ailede alkol kullanımı oranı çalışmamızda \%13 olarak bulunmuştur. Ailede alkol kullanımı ile ilgili bilgiye ulaşılan 289 olgu içinde değerlendirildiğinde ise bu oran \%25,6'ya çıkmaktadır. Bu oran, Dünya Sağlık Örgütü'nün 2000 yılında Türkiye'de genel alkol kullanımı için verilen \%19,6 oranından yüksektir (29). Bu sonuç ailede alkol kullanımının çocuğun istismara uğraması yönünde bir risk faktörü olması yönünde yorumlanmaktadır

Ülkemizde yapılmış olan cinsel istismar mağduru çocuk ve ergenlerin tanılarının değerlendirildiği bir çalışmada olguların poliklinik başvuruları sırasında DSM-IV tanı sınıflamasına göre yapılan psikiyatrik değerlendirmelerinde; travma sonrası stres bozukluğu (TSSB), akut stres reaksiyonu, uyum bozukluğu ve depresyon en s1k saptanan tanılar olmuştur (23). Bu çalışmada 294 vakanın geriye dönük ruhsal muayene sonuçlarına ulaşılabilmiş ve benzer şekilde en çok saptanan tanıların TSSB $(\% 13,6)$, uyum bozukluğu $(\% 9,2)$ ve depresyon $(\% 6,3)$ olduğu görülmüştür. Cinsel istismara uğrayan çocuk ve ergenlerde major depresyon, kaygı bozukluğu, travma sonrası stres bozukluğu, disossiatif bozukluklar, yeme bozuklukları, davranış bozuklukları, eliminasyon bozuklukları, cinsel kimlik bozuklukları gibi pek çok ruhsal bozukluk görüldüğü bilinmektedir (30).

Zoroğlu ve arkadaşlarının çalışmalarında (2001), çocukluk dönemi travmaları (istismar ve ihmal) ile kendine zarar verme ve özkıyım davranışı arasında çok güçlü bir ilişki olduğu anlaşılmaktadır. Fiziksel istismara uğramış ergenlerin \%43.8'i kendine fiziksel olarak zarar verme davranış1 göstermektedir. Bu oran cinsel istismar kurbanı ergenlerde \%45.6; duygusal istismar kurbanı ergenlerde $\% 42$ ve ihmal kurbanı ergenlerde \%41.6'dır. Çocukluk dönemi istismar ve ihmal yaşantılarıla, ergenlerdeki kendine fiziksel zarar verme davranışları, özkıyım girişimleri ve yüksek seviyede disosiasyon arasında güçlü bir ilişki bulunmuştur (31). Bu çalışmada \%2,7 kendine zarar verme, $\% 4,3$ intihar davranışı gözlenmiştir.

Çalışmamızda evden kaçma hikâyesinin nitelikli cinsel istismara maruz kalanlarda, ergen yaş grubunda ve kızlarda fazla olduğu ve DIS-Q ölçeği puanları ile korele olduğu saptandı. İntihar girişiminin ise kızlarda ve cinsel istismardan ruhsal açıdan etkilenmiş olanlarda fazla olduğu ve depresyon ölçeği puanları ile arasında pozitif korelasyon olduğu bulundu. Ülkemizde cinsel istismara uğrayan çocuk ve ergenlerde intihar ile ilişkili ruhsal özellikleri değerlendiren bir çalışmada \%14 oranında intihar girişimi saptanmıştır (26). Çalışmamızda intihar 
girişimi ile ilgili soruya cevap alınabilen 119 kişi değerlendirildiğinde intihar girișimi oranı \%20,2 olmaktadır. Önceki çalışmada intihar girişiminde bulunan olguların tamamının kız çocuk olduğu ve 13 yaş üzerinde intihar girișiminin anlamlı oranda arttığı belirlenmiş olup risk faktörleri değerlendirildiğinde zorlama ile vaginal-anal oral penetrasyon varlığında intihar girişimi riskinin 3.2 kat, TSSB varlığında 4 kat, depresif bozukluk varlığında ise 6.7 kat arttığı bulunmuştur (26). Kız çocuk, büyük yaş ve depresyon varlığı çalışmamızda da belirlenen ortak riskler olmakla birlikte diğer faktörlerle ilişki bulunamamıştır. Bu risk faktörlerine sahip olguların takibinde intihar riskinin hem klinisyen hem aile açısından göz önünde bulundurulması gerektiği yönünde önemlidir. Bu konuda yapılacak geniş örneklemli başka çalışmalarla bu risk faktörlerinin değerlendirilmesi ve genişletilmesi alana katkı sağlayacaktır.

Çalışmamız geniş bir örneklemin değerlendirilmesi amacı ile yapılmıştır ancak geriye dönük tüm verilere ulaşılamaması en büyük kısıtlllığı oluşturmuştur. Bu nedenle örneklem farklı sorularda farklı sayılarda olmuştur. Ayr1ca ölçeklerin kısıtlı sayıda vaka tarafindan doldurulmuş olması diğer önemli kısıtll11ıtır.

Çalışmada psikiyatrik bozukluklar dışında intihar ve kendine zarar verme davranışı gibi istismar sonrası gelişebilecek diğer durumlara da dikkat çekilmesi amaçlanmıştır. Diğer bir dikkat çekilmek istenen nokta ise ölçeklerde bozuklukların yüksek oranlarda çıkıyor olmasıdır. Özellikle disosiyatif bozukluğun istismara uğramış çocuklarda dikkatli değerlendirilmesi gerektiği düşünülmektedir. Evden kaçma davranışı ile ilişkisine baktığımızda tekrar kurban olma açısından da disosiyatif bozukluk gelişen çocuk ve ergenlerin büyük risk altında olduğu görülmektedir.

Sonuç olarak; çocukların cinsel istismarı çocuğu, ailesini ve toplumu ilgilendiren çok yönlü bir olaydır. $\mathrm{Bu}$ alanda ülkemizde geniş kapsamlı çalışmalara ihtiyaç vardır. Çocuklarda cinsel istismarın önemli bir halk sağlığı sorunu olduğu unutulmamalı ve uzun dönemde bir grup psikiyatrik bozukluk için risk etmeni olarak kabul edildiği akılda tutulmalıdır. Bu nedenle istismar olgularının gizli kalmaması, uygun kuruluşlara bildirimi, tedavi ve rehabilitasyonu çok önemlidir. Ayrıca çocuk ve ergen ruh sağlığ 1 alanında çalışan uzmanların cinsel istismara bağlı oluşabilecek risk etmenlerini ve psikiyatrik bozuklukları da göz önüne alarak konuyla ilgilenmeleri ve istismara uğramış çocuk ve ergenleri yakından ve uzun süreli takip etmeleri gerekmektedir.

\section{Kaynaklar}

1. 5237 say1lı Türk Ceza Kanunu [İnternet]. 2004 Eylül [alıntı 2016 May1s 30]. Mevcut adres: http://www.mevzuat.gov.tr/ MevzuatMetin/ 1.5.5237.pdf.

2. Putnam FW. Ten-year research update review: Child sexual abuse. J Am Acad Child Adolesc Psychiatry. 2003; 42(3): 269-78. doi: 10.1097/00004583 200303000-00006.

3. Stoltenborgh M, Van IJzendoorn MH, Euser EM, BakermansKranenburg MJ. A global perspective on child sexual abuse: Meta-analysis of prevalence around the world. Child Maltreat. 2011; 16: 79-101. doi:10.1177/1077559511403920.

4. Barth J, Bermetz L, Heim E, Trelle S, Tonia T. The current prevalence of child sexual abuse worldwide: a systematic review and meta-analysis. Int J Public Health. 2013; 58(3): 469-83. doi:10.1007/s00038-012-0426-1.

5. Pereda N, Guilera G, Forns M, Gomez-Benito J. The international epidemiology of child sexual abuse: a continuation of Finkelhor. Child Abuse Negl. 2009; 33: 331-42. doi: 10.1016/j.chiabu.2008.07.007.

6. Sedlak A, Mettenburg J, Basena M, Petta I, McPherson K, Green A et al. Fourth national incidence study of child abuse and neglect (NIS-4): Report to Congress. Washington D.C: US Department of Health and Human Services, Administration for Children and Families; 2010. Report No.: HHSP233200400058U, Contract no.: GS23F81144H.

7. Gilbert R, Spatz CW, Browne K, Fergusson D, Webb E, Janson $\mathrm{S}$ et al. Burden and consequences of child maltreatment in high-income countries. Lancet. 2009; 373(9657): 61-8. doi: 10.1016/S0140-6736(08)61706-7.

8. Goldman JDG, Padayachi UK. Some methodological problems in estimating incidence and prevalence in child sexual abuse research. J Sex Res. 2000; 37(4): 305-14. doi: 10.1080/00224490009552052.

9. İșeri E. Cinsel istismar. In: Çetin FÇ, Pehlivantürk B, Ünal F, Uslu R, İșeri E, Türkbay T, Coșkun A, Miral S, Motavallı N (eds). Çocuk ve Ergen Psikiyatrisi Temel Kitabı. 1.Bask1, Ankara, Hekimler Yayın Birliği, 2008: 470-477.

10. Duncan AE, Sartor CE, Schrerrer JF, Grant JD, Heath AC, Nelson EC et al. The association between cannabis abuse and dependence and childhood physical and sexual abuse: evidence from an offspring of twins design. Addiction. 2008; 103(6): 990-7. doi: 10.1111/j.1360-0443.2008.02210.x.

11. Paolucci EO, Genius ML, Violata C. A meta-analysis of the published research on the effects of child sexual abuse. Journal Psychology 2001; 135: 17-36. doi: 10.1080/00223980109603677.

12. Caspi A, Vishne T, Sasson Y, Gross R, Livne A, Zohar J. Relationship between childhood sexual abuse and obsessivecompulsive disorder: case control study. The Israel Journal of Psychiatry and Related Sciences. 2008; 45: 177-82.

13. Lee S, Lyvers M, Edwards MS. Childhood sexual abuse and substance abuse in relation to depression and coping. J Subst Abuse. 2008; 13: 349-60. doi: 10.1080/14659890802211077.

14. Afifi T. The relationship between child maltreatment and Axis I mental disorders: A summary of the published literature from 2006 to 2010. Open Journal of Psychiatry. 2012; 2: 21-32. doi:10.4236/ojpsych.2012.21004. 
15. Kovacs M. Rating scales to assess depression in schoolage children. Acta Paedopsychatr. 1980; 46: 305-15.

16. Öy B. Çocukluk Depresyonu Derecelendirme Ölçeği: Sağlıklı ve Çocuk Ruh Sağlığı Kliniğine Başvuran çocuklarda uygulanmas1. Türk Psikiyatri Dergisi. 1991; 2: 137-40.

17. Vanderlinden J, Van Dyck R, Vandereycken W, Vertommen H, Verkes RJ. The Dissociation Questionnaire (DIS-Q). Development and characteristics of a new self-reporting questionnaire. Clinical Psychology and Psychotherapy. 1993; 1: 21-7. doi: 10.1002/cpp.5640010105.

18. Şar V, Kızıltan E, Kundakçı T. Dissosiyasyon ölçeği'nin (DIS-Q) geçerlik ve güvenilirliği. 33. Ulusal Psikiyatri Kongresi Bildiri Kitab1; 1997; Antalya, Türkiye: 43-53.

19. Pynoos RS, Frederick C, Nader K, Arroyo W, Steinberg A, Eth $\mathrm{S}$ et al. Life threat and posttraumatic stres in school age children. Arch Gen Psychiatry. 1987; 44: 1057-63. doi:10.1001/archpsyc.1987.01800240031005.

20. Pynoos RS, Goenlian A, Tashjian M, Karakashian M, Manijikian R, Manoukian G et al. Posttraumatic stress reactions in children after the 1988 Armenian Earthquake. Br J Psychiatry. 1993; 163: 239- 47. doi: 10.1192/bjp.163.2.239.

21. Erden G, Kılıç EZ, Uslu RI, Kerimoğlu E. Çocuklar için travma sonrası stres tepki ölçeği: Türkçe geçerlik, güvenirlik çalışması. Çocuk ve Gençlik Ruh Sağlığı Dergisi. 1999; 6(3):143-49.

22. Soylu N, Pilan BŞ, Ayaz M, Sönmez S. Cinsel istismar mağduru çocuk ve ergenlerderuh sağlığını etkileyen etkenlerin araştırılması. Anadolu Psikiyatr Derg. 2012; 13:292-98

23. Öztop DB, Özcan ÖÖ. Cinsel istismar Vak'alarının Sosyodemografik ve Klinik Özelliklerinin
Değerlendirilmesi. New Symposium/Yeni Sempozyum. 2010; 48(4): 270-76.

24. Finkelhor D. The international epidemiology of child sexual abuse. Child Abuse Negl. 1994; 18: 409-17. doi:10.1016/0145-2134(94)90026-4.

25. Santos JC, Neves A, Rodrigues M, Ferrao P. Victims of sexual offences: medicolegal examinations in emergency settings. J Clin Forensic Med. 2006; 13: 300-3. doi: 10.1016/j. jcfm.2006.06.003

26. İmren SG, Ayaz AB, Yusufoğlu C, Arman AR. Cinsel istismara uğrayan çocuk ve ergenlerde klinik özellikler ve intihar girişimi ile ilişkili risk etmenleri. Marmara Medical Journal. 2013; 26: 11-6.

27. Erdoğan A, Tufan E, Karaman MG, Atabak MS, Koparan C, Özdenir E ve ark. Türkiye'nin dört farklı bölgesinde çocuk ve ergenlere cinsel tacizde bulunan kişilerin karakteristik özellikleri. Anadolu Psikiyatr Derg. 2011; 12: 55-61.

28. Acharya PN, Gill DS. The physical signs of child sexual abuse - an evidence-based review and guidance for best practice. British Dental Journal. 2008; 205: 55. doi:10.1038/ sj.bdj.2008.579

29. World Health Organization Department of Mental Health and Substance Abuse Global Status Report on Alcohol, Geneva, 2004.

30. Renteria SC. Summary: sexual abuse of female children and adolescents-detection, examination and primary-care. Ther Umsch. 2005; 62: 230-7. doi: 10.1024/0040-5930.62.4.230.

31. Zoroğlu SS, Tüzün Ü, Şar V, Öztürk M, Kora ME, Alyanak B. Çocukluk dönemi istismar ve ihmalinin olası sonuçları. Anadolu Psikiyatr Derg. 2001; 2(2): 69-78. 